\title{
THE UNIFORM SURVIVAL OF ACTIONS ACT
}

\section{W. F. BOWKER*}

In discussing this subject it is convenient to use the terms "victim" and "wrongdoer". The phrase "survival of action" means survival of a cause of action for the benefit of the victim's estate and also survival against the wrongdoer's estate.

The common law rule on the survival of causes of action in tort is actio personalis moritur cum persona. When the victim dies the cause of action never survives. When the wrongdoer dies it survives only where the claim is for the taking of property and it can be traced to the wrongdoer's estate.

It is now necessary to set out a second common law rule. No living person has a cause of action in tort against another who has wrongfully caused the death of a third. It has nothing to do with survival of actions but is often confused with that subject, because both rules come into play when a victim dies.

Legislation has made a great exception to the second rule. The Fatal Accidents Act ${ }^{1}$ gives a cause of action to certain specified dependents of the victim. If a plaintiff cannot bring himself within this class his action remains barred by the second common law rule.

The important point to remember is that a statute providing for survival of actions has nothing whatever to do with the second rule. It abrogates the first rule.

The first survival legislation in Canada appeared in Ontario in 1886 as a provision in the Trustee Act. The Northwest Territories borrowed Ontario's Act and Alberta kept it. Thus section 32 of Alberta's present Trustee Act ${ }^{2}$ provides for survival where the victim dies and section 33 where the wrongdoer does. The other western provinces have long had similar provisions. England had none until the Law Reform Act of 1934. ${ }^{3}$ Later each Maritime province passed a Survival of Actions Act based on the English Act. Newfoundland's survival provisions are in the Trustee Act, and are confined to torts to property.

In the past four years the Conference of Commissioners on Uniformity of Legislation in Canada has been studying the subject and preparing a Uniform Survival of Actions Act. The work is now complete and the Act will appear in the 1963 Proceedings to be published in the spring of 1964.

Since the Uniform Act, if adopted in Alberta, would make one important change and several minor ones in our law it seems appropriate to bring it to the attention of the profession. Before discussing the Act itself I would like to use the occasion to say a word about the work of the Uniformity Conference in general. It has representatives from all provinces and the federal government. Its purpose appears from its name.

- Wubur Fee Bowker, Q.C.. B.A., LL.B. (Alta.) LL.M. (Minnesota), Dean of the Faculty of Law, Universlty of Aiberta. This artlcle is a revised version of a paper dellvered at the February meeting of the Alberta section of the Canadian Bar Association.

1 R.S.A. 1955 c. 111.

2 R.S.A. 1955 c. 346.

3 (Imp.) $24 \& 25$ Geo. 5 c. 41. 
Established by the Canadian Bar Association it has had an independent existence for forty-five years. In that period it has produced many model or uniform acts. Among those enacted in whole or in part by the Alberta legislature are: Rules of the Road (in the Vehicles and Highway Traffic Act $^{4}$ ), Evidence ${ }^{6}$, Wills, ${ }^{\circ}$ Intestate Succession, ${ }^{7}$ Devolution of Real Property, ${ }^{8}$ Family Relief, ${ }^{,}$Bills of Sale, ${ }^{10}$ Conditional Sales, ${ }^{11}$ and miscellaneous statutes ranging from Legitimation ${ }^{12}$ to the Cornea Transplant Act. ${ }^{13}$

The Conference always welcomes the help of the profession in its work of preparing uniform Acts. For example, provincial Law Reform Committees could do much to assist the Conference; likewise provincial Law Societies and the Canadian Bar Association. Indeed in the case of th Companies Act, the latter body has been of great help in the attempt to achieve uniformity.

Once the Conference has adopted a Uniform Act, its introduction into the legislature depends on the Cabinet. Nearly all uniform acts have been passed in at least one province and a few in almost all. Of course a legislature may adopt a uniform act with amendments, or having adopted it in toto may later amend it. It seems obviously desirable for the profession to know the content of any uniform act that the Cabinet may bring before the Alberta legislature. Of course uniform acts have always been published and the contents of any bill before the legislature are ascertainable. However the profession does not always make a point of examining these sources and it seems proper and desirable to call the profession's attention to proposed legislation-or potential legislation, as one might call a Uniform Act. Hence the following comments on the Uniform Survival of Actions Act.

All the existing acts have a general provision that causes of action survive, as one would expect in a statute designed to provide for survival. However, nearly all of the Acts contain exceptions. In Alberta, the only one is libel and slander. In other Acts one finds one or more of the following: malicious prosecution, false imprisonment, enticement of a spouse, adultery, defamation." In every case these exceptions apply both when the victim dies and when the wrongdoer dies. Yet there is in fact an important difference between the two situations. Where the wrongdoer dies the plaintiff is still alive and his damages are not mitigated in any way by the wrongdoer's death. Therefore, the wrongdoer's death should make no difference. (One can concede an exception in the case of purely exemplary damages, but as the House of Lords recently pointed out in Rookes v. Bernard, ${ }^{15}$ truly exemplary damages are very exceptional in English tort law). For this

4 (Alta.) 1958 c. 93 , amending R.S.A. 1855 c. 356.

5 R.S.A. 1955 c. 102 .

6 R.S.A. 1955 c. 369 and (Alto.) 1960 c. 118

7 R.S.A. 1955 c. 161 .

R.S.A. 1955 c. 89.

- R.S.A. 1955 c. 109.

10 R.S.A. 1955 c. 23.

12 R.S.A. 1955 c. 54.

12 (Alta.) 1960 c. 56.

18 See Trustee Act, R.S.A. 1955 c. $346,89,32-33,1960$ c. 111; Administration Act, R.S.B.C

1960 c. 3, s. 71; Trustee Act, R.S.M. 1954 c. 273 , s. 49 ; Survival of Actions Act. R.S.N.B.

1952 c. 223 ; Trustee Act, R.S.Nfld. 1952 , c. 166, B. 22; Survival of Actlons Act. R.S.N.S.

1954, c. 282; Survival of Actions Act. 1955 (P.I.I.) c. 17; Trustee Act, R.S.S. 1953, c. 123,

16 (H.L. (E.)) [1964] 1 All E.R. 637. 
reason the Uniform Act simply provides ${ }^{18}$ that when the wrongdoer dies causes of action against him shall survive. None of the exceptions in the various existing acts is brought into the Uniform Act.

The death of the victim, however, raises different considerations. Torts that cause property damage or any actual loss to the victim's estate should survive in its favour. On the other hand, there are certain damages that a living plaintiff should be able to recover, but that his estate should not be able to. For this reason the section providing for survival of causes of action where the victim dies makes an exception of actions for adultery, seduction and enticement. ${ }^{17}$ These can be described as especially personal in nature. (The English Act ${ }^{18}$ contains $^{2}$ this exception though that Act extends it to the case of the death of the wrongdoer as well as the victim.) In addition the Uniform Act provides that in cases where the action does survive for the benefit of the victim's estate, there is a restriction on the amount of damages that may be awarded.18 This is the provision that if enacted here would do away with the claim for loss of expectation of life. It provides:

6. Where a cause of action survives for the benefit of the estate of a deceased person, only damages that have resulted in actual pecuniary loss to the deceased person or the estate are recoverable and, without restricting the generality of the foregoing, the damages recoverable shall not include punitive or exemplary damages or damages for loss of expectation of life, pain and suffering or physical disfigurement.

(England has a similar restrictive provision but it does not include claims for loss of expectation.)

It is important to point out the reason for the exceptions in section 3 and the restrictions in section 6 . It is this. The basis of damages in tort is compensation. Survival of a cause of action for the benefit of the victim's estate should be to enable the estate to recover pecuniary losses but nothing more. The common law rule clearly worked a hardship where the wrongdoer negligently burned down the victim's barn or smashed his car, and by chance the victim died of a heart attack before he could take action and obtain judgment. However, there are some items of damage that are in a different category. Like claims for adultery, seduction and enticement, they are peculiarly personal. Compensation for pain and suffering, disfigurement, and loss of expectation of life and heavy damages for defamation, false imprisonment and malicious prosecution are the main examples. To allow them to the victim's estate as one would allow them to the victim himself is to give to the estate a windfall. The late Professor Winfield once expressed this view:

"Where it is the tortfeasor who has died, then whether the tort was a personal one or not, his estate ought to be liable. Where it is the injured party who has died there is something to be said for extinction of an action for a personal tort, for it seems consonant neither with justice nor with the law of tort that a man's successors should profit by a wrong which in origin did them no harm; if, however, they are in fact harmed, as might woll happen in some cases of defamation of their predecessor, then his remedy ought to survive."

Since the claim for loss of expectation is of particular interest in Alberta, and my purpose here is to support the abolition of that claim,

18 s. 4.

17 s. 3.

18 supra, n. 3.

$10 \mathrm{~g} .6$.

2014 Can. Bar Rev. 639, 649. 
it will help to give its history. Although Ontario has had its survival provisions from 1886 and Alberta since Territorial days, I have never found any suggestion of such a claim in any Canadian case or literature until after the English Courts had accepted it under that country's survival legislation of 1934 . In 1935 the Court of Appeal considered a case ${ }^{21}$ in which the victim was still alive and the evidence showed that because of his injuries he would probably not live as long as he normally would have been expected to. The Court held this is a proper item to consider in awarding damages to the living victim. Then came Rose v. Ford ${ }^{22}$ in which a 22-year old woman died as a result of the defendant's negligence. Her estate brought action under the survival legislation and claimed that since the victim could have claimed for loss of expectation had she lived, the estate may likewise do so even though the shortening of life is no longer an expectation but an accomplished fact. The House of Lords admitted the claim. Four years later in recognition of the impossibility of putting a money value on expectation of life where the victim had died, the House of Lords in Benham v. Gambling ${ }^{23}$ ruled that the damages should be kept low and in effect set the amount at $£ 200$. In recent years the amount has risen to as much as $£ 500$.

In Canada in the meantime, Rose v. Ford was the inspiration for many actions by estates where the victim had died after an accident for which the defendant's negligence was responsible. In the next few years all the common law provinces except Alberta and Manitoba abolished the claim for loss of expectation. The courts of those two provinces and the Supreme Court of Canada are still struggling with attempts to put a value on life for the purpose of actions under the Trustee Act. The awards have ranged from $\$ 1,000$ to $\$ 7,500$. A common figure nowadays is around $\$ 6,500$.

In deciding that the Uniform Act should abolish the claim for loss of expectation, the Conference of course knew that all provinces but two have already done away with it as a matter of deliberate legislative policy. This fact taken by itself would not be sufficient reason for following suit. The Conference was of opinion that abolition is sound in principle. The amount of the award is essentially arbitrary. I do not suggest that mere difficulty in assessment is of itself a reason for rejecting a claim. Everyone recognizes the difficulty of determining quantum in almost any case of personal injuries, but here it seems no exaggeration to say there is no rational basis at all. The main reason, however, is more fundamental. In the law of negligence the purpose of an award to a plaintiff is compensation for loss he has suffered. Here however the estate has suffered no loss whatever. An award is a simple windfall which it would not be were the victim alive. In that case he would himself receive the money (and incidentally such awards are rare, so far as reported cases show). Supporters of the claim for loss of expectation might argue that the award will benefit the estate. The answer is that it is of no practical assistance to dependents because they have their action under The Fatal Accidents Act. ${ }^{24}$ Usually their damages thereunder are greater than the award for loss of expectation and

21 Flint v. Lovell [1935] 1 K.B. 354.

22 (H.L. (E.)) [1937] A.C. 826.

29 (H.L. (E)) [1941] A.C. 161.

24 supra, n. 1. 
the amount they receive under the Trustee $\mathrm{Act}^{23}$ is deducted from their damages under the Fatal Accidents Act. Thus the argument that judgments for loss of expectation serve the purpose of helping dependents under the Fatal Accidents Act is not available. The only ones who benefit from the award are beneficiaries who are not dependents, or creditors.

Another argument used by proponents of the claim is that the law should not make it cheaper to kill than to main. The answer is that we are not in the realm of punishment but of compensation. A serious injury may well result in smaller damages than a less serious one.

It must be remembered that survival legislation does not confer a cause of action for wrongful death. Yet in effect an award for loss of expectation operates to give the victim's estate such an action. Indeed, one Manitoba judge ${ }^{20}$ said that this was the purpose of the legislation! There is no need here for an extended discussion of the logic of the claim. The conflicting viewpoints emerge in the Court of Appeal judgment in Rose v. Ford ${ }^{21}$ itself. My submission is that the award in fact if not in form is one for wrongfully causing death-and the Act permits no such claim. Middleton J. so held in Ontario over forty-five years ago. ${ }^{28}$

$I$ am content to support the criticism of Fleming, ${ }^{20}$ and Stone: ${ }^{30}$ and to adopt the reasons of Dean Wright ${ }^{31}$ and of E. R. E. Carter ${ }^{32}$ in favour of abolition.

By way of summary, the purpose of survival legislation is to cure defects in the common law. The present submission is that the real harshness of the common law rule disappears once the victim can recover against the wrongdoer's estate, and the victim's estate can recover for loss to the estate. The legislation should not cast its net so wide as to allow the estate of a victim to make a claim that represents no loss whatever to the estate. If the Fatal Accidents Act is too narrow it should be widened; and a Survival Act should not be the vehicle for doing this indirectly, erratically and inefficiently.

By way of a postscript, may I mention the provision for limitation of actions." If enacted it would overcome the decision in Scott $v$. Thompson," holding that the period prescribed in the Vehicles and Highway Traffic Act ${ }^{3 s}$ prevails over that in the Trustee Act. ${ }^{30}$

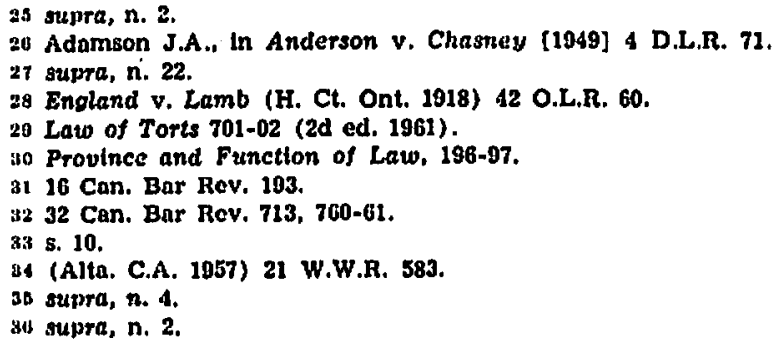

